\title{
BREVI NOTE
}

Riv. ital. Orn., Milano, 80 (1): 57-59, 31-XII-2010

\section{SOME OBSERVATIONS ON NESTING AFRICAN GREY PARROTS, Psittacus erithacus, IN UGANDA}

\author{
Riassunto - Osservazioni sulla nidificazione del Pappagallo cenerino, Psittacus \\ erithacus, in Uganda.
}

African Grey Parrots' breeding biology is far less known in the wild than it is in captivity. The few existing ecological studies (MC GOWAN, 2001; NGENYI, 2002) have generally focused on estimation of their populations and/or habitat associations (Bennum et alii, 1996; CRUICKSHANK et alii, 1993; TAMUNGANG \& AJAYL, 2003; Amuno, 2004). In January 2003 we had the chance to find a first nest of African Grey Parrot in Budongo Forest Reserve, soon followed by a second one in March 2003 at Lubowa estate, Entebbe road, both of them in Uganda. We then conducted observations on these two active nests of African Grey Parrots, both of them located in a rather unusual type of habitat, that is the forest fringe in the case of Budongo nest and even a residential area in the case of Lubowa.

In Budongo the nest was located on an isolated very large tree of Schreibera arborea at about 20 meters from the ground, before the main bifurcation of the trunk into large branches. Our observations were conducted from January 3 to February 6, starting at 5.30 am local time and ending when the last of the breeding pair re-entered the nest.

Initially we stayed at the nest through the whole day, waiting until the breeding pair re-entered the nest, as it became dark. Later, according to the findings of the first observations, we broke any further observations into two different times of the day, that is the morning from 5.30 until about $11.00 \mathrm{am}$ and the evening from $5.00 \mathrm{pm}$ until it became so dark to make impossible any further observation. During the preliminary observations we noticed that both the components of the breeding pair came out of the nest at the very early light, generally between 6.22 to $6.38 \mathrm{am}$. Before they emerged or made any call, the chicks would be heard uttering their food-begging or other types of calls for a few seconds to about two minutes. Subsequently both adults would appear at the nest hole and make a short "flight call" before flying away promptly. They 
first came back to the nest between 7.41 and $9.30 \mathrm{am}$, both entering the nest for a few minutes. After this, in most cases one of the breeding pair, presumably the male, left again while the other, presumably the female, stayed in the nest and remained quiet and still, showing no sign of presence for several hours, usually up to late afternoon. Only at that time, usually between 5.30 and $6.00 \mathrm{pm}$, did the presumptive female come out, she did utter calls and finally left into the same direction followed in the morning.

The presumptive male did usually come back in the evening, between 6.00 and $7.30 \mathrm{pm}$, sometimes together with the presumptive female, some other time without her. However, when the female was not there, the male was not entering the nest but was either staying around vocalizing or flying away again. When the pair was finally coming back together, both birds were often engaging in duets for several minutes, at times flying around the nest and perching on nearby trees. However, in some instances, the male would not return to the nest until the following day, leaving the female alone with the chicks. In addition it was noticed that, as the chicks grew older, the female was not always staying at the nest for the whole day as in the earlier stages, but she would leave for several hours of the day before returning to the nest in the late evening.

Among the potential nest competitors, the presence was noticed of a pair of Grey Kestrels, Falco ardosiaceus, and several pairs of Black and white casqued Hornbills, Bycanistes subcylindricus. The former, in one instance, attacked the parrots that were then seen to look for cover unusually near the ground. In other instances, when the returning parrots found any of these potential competitors perching on the nest tree, they would not enter the nest, but would rather fly away or perch on nearby trees and continue to utter calls.

It would appear, therefore, that, while parental care is shared between male and female, the female plays a more direct role by brooding, possibly feeding, cleaning and protecting the hatchlings from any possible external interference. However, as the chicks grow, the female takes a longer time away from the nest so that the chicks are exposed to higher potential risks. In fact, in the case of our Budongo nest, the brood was terminated by the interference of a pair of Black and white casqued Hornbills that killed the chicks and disposed of their bodies before taking over the nest cavity for their own breeding (KALINA, 1988).

In the second case, the Lubowa nest, the single chick present in the nest was removed by a human wishing to sell it and it was rescued through a coordinated action of the wildlife authorities together with the local police and the local community. No detailed observations were conducted at this particular nest.

Therefore, disturbance factors, though differed in type, had similar effects on brood, although, in one case, both hatchlings were lost while in the other the single one was recovered. Studies, detailed in scope and sustained in time, should attempt to trace, isolate and evaluate the impacts of various disturbance/threat factors on the breeding biology/ecology of African Grey Parrots. It is then that management decisions embracing favourable habitat protection and community education approaches may reduce losses due to human induced threats and changes. 
Acknowledgements - This work was supported by a grant from the Parco Faunistico "Le Cornelle" of Valbrembo, Italy. We are also grateful to WARM Department and especially to prof. Christine Dranzoa for facilitating us in various ways.

\section{REFERENCES}

Amuno J.B., 2004 - A survey of distribution, abundance and habitat use by Grey parrot Psittacus erithacus in Budongo and Mabira forest reserves, Uganda. - M.S. thesis, Makerere University, Kampala.

Bennum L., Dranzoa C. \& Pomeroy D., 1996 - The forest birds of Kenya and Uganda - Journal of East African Natural history, 85: 23-48.

CRuickshank A.J., Gautier J. \& Chappuis C., 1993 - Vocal mimicry in wild African Grey Parrot Psittacus erithacus - Ibis, 135: 293-299.

KALINA J., 1988 - Ecology and Behavior of the Black and white casqued Hornbill (Bycanistes subcylindricus subquadratus) in Kibale Forest, Uganda - PhD Dissertation, Michigan State University, Michigan.

McGowan P., 2001 - Status, Management and Conservation of the African Grey Parrot (Psittacus erithacus) in Nigeria - CITES Secretariat, International Environment House Geneva, Switzerland.

NGenyi A., 2002 - African Grey Parrot trade in Cameroon, Lobeke National Park. - Psittascene, No. 51: 2-3.

Tamungang S.A \& AJaYI S.S., 2003 - Diversity of food of the Grey Parrot Psittacus erithacus, in Korup National Park, Cameroon - Bulletin ABC, 10 (1): 33-36.

John B. Amuno

Department of Wildlife and Animal Resources Management (WARM), Makerere University - P.O. Box 7062 - Kampala - Uganda

RenAto MASSA

Department of Environmental and Landscape Science University of Milan Bicocca - Piazza della Scienza, 1 - I-20126 Milano - Italy Present address: Via Mammianese, 167 - loc. Goraiolo - I-51010 Marliana PT - Italy

Geoffrey OKethowengo

C/o Budongo forest project - P.O. Box 362 - Masindi - Uganda

Riv. ital. Orn., Milano, 80 (1): 59-61, 31-XII-2010

\section{BIRDS ON THE ROADS: A PRELIMINARY NOTE FROM CENTRAL ITALY}

RIASSUNTO - Uccelli sulle strade: dati preliminari dall'Italia centrale.

Road ecology is a new disciplinary arena (FORMAN \& AlEXANDER, 1998). Despite research on negative effect on birds of roads with high volume of motor vehicle traffic are widely available in recent literature (e.g., HoDsON, 1962; vAN DER ZANDE et alii, 1980; REIJNEN et alii, 1995, 1996), data on their active use as feeding sites are very lacking (LAURSEN, 1981; BENNETT, 1991). 